"Opportunities and Limitations in the Teaching of Endocrinology at the pre-University Level". The final session will be thrown open for discussion on the points raised by the speakers earlier in the day. Applications for tickets (price 6s.) should be made to the Secretary, Joint Biology Committee, c/o British Social Biology Council, Tavistock House South, Tavistock Square, London, W.C.1, from whom further particulars may be obtained.

\section{Exhibition of Kinematography in London}

AN exhibition of kinematography, comprising films, wall displays and apparatus, will be held by the Kinematograph Group of the Royal Photographic Society in the Society's House, 16 Princes Gate, London, S.W.7, during December 3-18. The exhibition revives an event held regularly before the outbreak of the Second World War. The films will be divided into five sections on the application of kinematography to, respectively, industry, science, medicine, education and other specialized fields. Lectures and demonstrations will also be given. Films for the exhibition may be submitted in any gauge, sound or silent, black-and-white or colour, but the running-time of any one film should not exceed forty-five minutes. It is not essential that films should be the work of one person; they cen be made by groups, societies or commercial undertakings. Intending entrants should obtain an entry form as soon as possible from the Honorary Secretary, Kinematograph Group (Exhibition Committee), 16 Princes Gate, London, S.W.7, and return Part 1 of the form, duly completed, as soon as possible. The films, accompanied by Part 2 of the entry form, should be sent in by October 30 .

\section{Radio Industry Council Awards}

Since January 1, 1952, the Radio Industry Council has awarded premiums of 25 guineas each, up to an average of six a year, to writers of published articles, the object of the premiums being to encourage the publication of articles reporting technical progress and development of radio, television and electronics in Great Britain. The main points to be taken into consideration will be the value of the article in making known British achievement in radio and electronics; the originality of subject; technical interest; and presentation and elarity. Any writer will be eligible who is not paid a salary wholly or mainly for writing and not earning 25 per cent or more of his income from fees for articles or from book royalties. For articles written jointly, each author must be eligible, and the premium will be divided. Papers or periodicals which can be bought by the public on bookstalls or by subscription, at home or abroad, will be eligible, but not journals circulating exclusively to members of a trade, manufacturers' journals, or the privately published journals of professional institutions or learned societies. Entries should be made before December 31 by submitting five copies of the published article to the Secretary of the Radio Industry Council, 59 Russell Square, London, W.C.1.

\section{Announcements}

The nineteenth Parsons Memorial Lecture will be delivered at the Institution of Mechanical Engineers by Mr. F. Dollin on October 29 at 5.30 p.m.; Mr. Dollin will speak on "Factors Influencing the Continuing Development of the Steam Turbine".
IN connexion with the celebration of the jubilee of the invention of the thermionic valve by Sir Ambrose Fleming on November 16, 1904, a conversazione and exhibition will be held during November 16-18 in the Electrical Engineering Department of University College, London, and a plaque commemorating the occasion will be unveiled by the Lord President of the Council. Admission is by ticket, application for which should be made to the Assistant Secretary, University College, Gower Street, London, W.C.1.

The twenty-eighth annual general meeting of the Bedson Club will be held in the Chemical Laboratories, King's College, Newcastle upon Tyne, on October 15, after which Prof. T. S. Westoll, J. B. Simpson professor of geology in King's College, will deliver a lecture on "Fossils I have Known". Other Bedson Lectures for 1954-55 are: Prof. A. R. Ubbelohde, "Some Physicochemical Studies on $\pi$-Electron Compounds" (October 29) ; Dr. F. G. Mann, "The Comparative Organic Chemistry of N, P and As" (November 12); Dr. R. P. Bell, "The Place of Theoretical Chemistry in Chemical Education" (February 11); and Prof. F. J. W. Roughton, "Rapid Reactions of Hæmoglobin with $\mathrm{O}_{2}$ and CO" (March 11).

British Celanese, Lto., announces the award of research studentships in chemistry, tenable for two years from October 1 at the institutions mentioned, as follows: Mr. R. B. Pearson (University College, London), Mr. A. M. North (University of Birmingham), Mr. J. L. Tayler (Imperial College of Science and Technology, London) and R. L. Vale (University of Birmingham).

THe Department of Agriculture for Scotland has awarded the following postgraduate scholarships in a.gricultural subjects, tenable for periods up to three years, commencing in Oetober at the university or centre shown : Husbandry: I. C. Beattie, J. Frame, I. A. Munro and Miss S. M. Sweeney (University of Reading); D. C. Graham (University of California); A. M. M. McFarquhar (University of Leeds); Miss M. W. Murray (Ohio State University); W. C. Smith (Massey Agricultural College, New Zealand). The following current awards are being continued for a further period : Husbandry: J. Eadie (University of Edinburgh); T. D. MacLean (University of Reading); T. M. Sutherland (Iowa State College); Agricultural Economics : A. V. Vickery (Agricultural Fconomics Research Institute, Oxford); Agricultural Engineering : J. Roddan and J. H. S. Torrance (King's College, University of Durham).

A Conference on "Design and Application of Small Digital Computers" will be held at the Bellevue-Stratford Hotel, Philadelphia, during December 8-10. The programme includes papers on computer comparisons, input-output devices, computer systems and characteristics, mathematics, programming, and business and scientific applications. Further information can be obtained by writing to $P$. $O$. Box 7825, Philadelphia 1, Pa.

REFERRING to the communication entitled "Velocity of Electron Pulses" published in Nature of August 28, p. 398, the authors write: "We regret we omitted acknowledging the generous assistance of Imperial Chemical Industries, Ltd., which enabled one of us (D. L. R.) to carry on the work in the first year, and the maintenance grant of the Department of Scientific and Industrial Research, for the second year of these investigations". 